\title{
Cumhuriyet Döneminde Kahvehanelerin Mekânsal İşlevselliği ve Siyasal Figür Olarak Kahvehaneler
}

\author{
İsmail SAFi \\ İstinye Üniversitesi İktisadi İdari ve Sosyal Bilimler Fakültesi, Siyaset Bilimi ve \\ Kamu Yönetimi Bölümü. \\ isafi@istinye.edu.tr
}

\begin{abstract}
$\ddot{\mathbf{O} z}$
Araştırmanın amacı Osmanlı İmparatorluğu'ndan bir miras olarak Türkiye Cumhuriyeti'ne kalan kamusal alandaki kahvehanelerin siyasi ortamın şekline göre değişimlere uğraması ve güncele adapte olup olmadığıdır. Türk siyasi hayatında kırılmaların yaşandığı yıllarda kahvehaneler kamusal alanda siyasetin en çok etkisinde kalan yer olmuştur. İktidarın politikalarını benimsetmeye çalıştığı, partilerin propagandalarını yaptığı ve siyasetteki kutuplaşmaların vücut bulduğu alan olmuştur. Siyasi otoritenin her zaman için etki alanı içinde tutmayı arzuladığı bu mekânlar toplum tarafından sık uğrak yerleri olmuştur. Kahvehaneler sadece siyasetin konusu olmamış, aynı zamanda dönemin kültür hayatının da etkin bir parçası olmuştur. Siyaset ve kültürel hayatla bu kadar iç içe geçmesi sonucu, kahvehaneler Türkiye'ye özgü bir yapı hali gelmiştir. Özellikle 40'lı ve 50'li yıllarda üniversite çevresindeki kahvehaneler, dönemin aydınlarının buluşma noktası haline gelmiş ve kültürel yaşamda kültürel üretim mekânı haline gelmiştir. Bu çalışmada, kahvehanelerin sosyal kaynaşma aracı olmasının yanı sıra, dönemin siyasi yapısına göre farklılık gösterdiği ve dönemin siyasal ruhunu diğer kamusal alanlara göre daha çok barındırdığı sonucuna varılmıştır. Özellikle Türk siyasi tarihinde sol-sağ çatışmalarının yaşandığı yıllarda kahvehanelerin mekânsal değişiminin siyasi etkileri ve sonuçları ortaya çıkmıştır. 70’lı yıllardan itibaren giderek siyasi çatışmanın içinde yer kalan kahvehanelerin, 80 darbesi sonrasındaki ekonomik yapının değişimine ayak uydurması gözlemlenmiştir. Ekonomik değişimlerin sonucu olarak, kahvehaneler giderek depolitize olmuştur. Liberal ekonomi politikalarının da etkisiyle birlikte, artık kahvehanelerin yerlerini kafe/kafeteryalar almıştır.
\end{abstract}

Anahtar Kelimeler: Kahvehane, Siyaset, Türk Siyasal Hayatı, Sosyo-ekonomik Değisşim.

\section{Spatial Functionality of Coffeehouses in the Republican Period and Coffeehouses As Political} Figure* $^{*}$

\begin{abstract}
The purpose of the research is to understand if the coffeehouses in public sphere have adapted to the alteration with the political sphere from Ottoman Empire to Republic of Turkey. The coffeehouses turned out to be the locations which had been influenced by the politics during major changes in Turkish political life. These locations became the cradle for propagating political party programs along with the government's propaganda, thus also became the cradle of political polarization. These locations, after visited by public, turned out to be places which political authority desired to influence. Coffeehouses didn't only became a topic at politics, but also played a significant role in cultural life. So, embracing both politics and cultural the coffeehouses in Turkey assumed a unique role. Especially in 40 's and 50's, the coffeehouses located around universities became a meeting point for the intellegencia and also a place for intellectual production. In this study, it is understood that the coffeehouses along with being a socialization space, they also differed according to the political structure of the era and reflects the political essence much better and more compared to other places public sphere. Especially during the spatial changes at coffeehouses political impacts and results were emerged. The adaptation of coffeehouses were observed, from the political disputes of 70's to the economics changes in the post 80 coup d'état. As a result of the economic changes, coffeehouses have become depoliticized. Nowadays with the influence of liberal economic policies, cafeterias take the place of coffeehouses.
\end{abstract}

Key words: Café/coffeehouse, Politics, Turkish Political Life, Socio-economic Change.

${ }^{*}$ Extended abstract is presented at the end of the article.

Atıfta bulunmak için/Cite this paper:

Safi, İ.. (2018). Cumhuriyet Döneminde kahvehanelerin mekânsal işlevselliği ve siyasal figür olarak kahvehaneler. Çankırı Karatekin Üniversitesi IIIBF Dergisi. 8 (2), 293-304. 


\section{Giriş}

Osmanlı Devleti'nin son dönemlerinde ve Cumhuriyet'in ilk dönemlerinde, yüzyıllardır var olan kahvehanelerin hem yapıları hem de işlevsel özellikleri keskin olarak değişime uğramıştır. Bu olguda kuşkusuz değişen dünya, siyaset ve ekonomi etkiliydi. 19. yüzyılın son çeyreğiyle birlikte devlet değişiyor, hatta deyim yerindeyse hızlıca modernleşiyordu. Bu süreçte devlet ile birlikte toplum ve kurumlar siyasal, ekonomik ve yapısal olarak değişimler geçirmeye başladılar. Elbette bu değişim ve dönüşüm süreci birçok anlamda sosyo-politik olaylara sebebiyet vermiştir. $\mathrm{Bu}$ süreçte kahvehaneler ve kahvehaneler gibi toplumun uğrak mekânları mecburen iki seçenek arasında kalmışlardır: ya değişime ayak uyduracaklar ya da kaybolup gidecekler ve tarihe karışacaklardı. Nitekim canlı bir organizma gibi hareket ederek, kahvehaneler belirli evrimler geçirerek günümüze kadar ulaştılar.

Çalışmada kahvehanelerin Osmanlı Devleti zamanından günümüze kahvehanelerin geçirdiği evrimsel süreci ve sosyo-politik işlevleri üzerinde durulacaktır. Cumhuriyet döneminde kahvehanelerin serüvenini ele alırken aslında öncü dönem olan ikinci meşrutiyetten başlanacaktır. İlk olarak ikinci meşrutiyetten günümüze kadar kahvehanelerin nasıl bir siyasal mekân olduğunu, daha sonra artık kahvehanelerin daha önce olduğu gibi ortak toplumsal kaynaşma yeri olmaktan giderek nasıl uzaklaştığını ve son olarak da kahvehanelerin günümüzde nasıl evrim geçirerek modern, seküler kafelere dönüştüğünü incelenecektir.

\section{Siyasi Bir Figür Olarak Kahvehaneler}

Osmanlı Devleti'nde kahvehaneler eğlence kültürü içerisinde büyük önem taşıyan mekânlardı (Hattox, 1998, s. 65). Fiziki ortam ve çalışma tarzı bakımından sunulan ürün ve hizmetin dinen yasaklanmamış/meşru bir ürün olması, kahvehaneleri çekinmeden gidilen mekânlar haline getirmiştir. Zaman içerisinde, halkın yönetimle ilgili görüş ve yakınmalarını açığa vurduğu yerlere dönüşen kahvehaneler, toplumun siyasallaşması açısından da önemli bir dinamik yaratmıştır. Ne var ki, kent yaşamına yönelik ortaya çıkardıkları bu dinamiğe karşın, özellikle din görevlileri, kahvehanelerin kendi nüfuz alanlarını daraltan bir kullanım alanı olduğunu iddia etmişler; bu yüzden iktidar ve yakın çevresi de söz konusu yerlere sürekli olarak kuşku ile yaklaşmışlardır (Hattox, 1998, s. 5). Öyle ki, bu kuşku, kahvehanelerin günlük siyasal olayların konuşulduğu, devlet işlerinin eleştirildiği yerler haline geldikleri gerekçesiyle IV. Murad (1623-1640) tarafından kapatılmasına kadar varmıştır. Ancak, farklı dönemlerde birçok yasak ve kısıtlama ile karşı karşıya kalan kahvehaneler uzun süre kapalı tutulamamıştır.

Tarihsel olarak baktığımızda, kahvehaneler 19. yüzyıl siyasetinde önemli bir unsurdur. İlk resmî gazete Takvim-i Vekayi (1831) ile birlikte kahvehaneler gazete ile tanışmış; toplumsal ve siyasal anlamda kahvehanelerin önemi artmıştır. 
Gazete, ilk olarak kahvehanelerdeki yerini alan kitle iletişim aracıdır ve günümüze kadar kahvehanelerin ayrılmaz bir parçası haline gelmiştir. Gazetenin kahvehanede yer almaya başlamasından sonra kahvehanede sesli bir şekilde gazete okumak yeni bir etkinlik olarak ortaya çıkmış ve gazetede yer alan haberlerden, gündemden haberdar olmak isteyenler kahvehanelere gelmeye başlamışlardır. Kısaca gazete sayesinde kahvehane müşterilerinin sayısı artmıştır. Elbette toplumda okur-yazarlık oranının düşük olması bunda etkili olmuştur. Toplu olarak gazete okuma faaliyeti sayesinde basın, geniş halk kitlelerine ulaşmış, kahvehaneler de burada önemli bir araç haline gelmiştir. Böylece kamuoyu oluşturmada kahvehaneler çok önemli bir konuma gelmiştir. Hatta bu noktada kahvehaneler için kanaat önderlerinin basınla buluştuğu, toplumsal ve siyasal yaşama yön vermeye çalışıldığı önemli bir mekân haline geldiği söylenebilir.

Devlet ya da devlet gücünü kullanan siyasal iktidar kendi gazetesiyle kahvehanede propaganda yapma imkânı bulmuş ama bu durum kısa sürmüştür. Çünkü hemen ardından bu kez muhalefet de kendi gazeteleriyle kahvehanelere girmiş ve bu andan itibaren kahvehaneler aktif siyasetin merkezinde yer almaya başlamıştır. Öyle ki Tanzimat, Kırım Savaşı, Meşrutiyet İlanı gibi konuların en fazla konuşulduğu ve tartışıldığı mekân kahvehanelerdir. İşte bu yüzdendir ki siyasal iktidar, bu mekânları kontrol etme ihtiyacı duymuş ve sık sık denetlemeye başlamıştır. II. Abdülhamit'in istibdat döneminde istihbari görevlilerin jurnal almak için en uygun buldukları yer kahvehanelerdi. Bunun yanında, kahvehaneler muhalifleri için de yaşam alanı olmuştur.

İttihat ve Terakki Cemiyeti'nin Abdülhamit devrindeki gizli faaliyetlerinde kahvehaneler sürekli olarak önemli yer idi. Özellikle askeri okul öğrencileri için kahvehaneler adeta bir buluşma ve toplantı yeri olarak belirleniyordu. Gizlilik içerisinde hareket eden öğrencilerin faaliyetleri ilk zamanlar, okullarında olsa da, daha sonraları yakalanmamak için 'Hatab Kıraathanesi' ve 'Edirnekapı İnciraltı Kıraathanesi' gibi yerlerde gerçekleşiyordu ve gizli çalışmaların sürdürüldüğü yerler burasıydı (Gökbayır, 2012, s. 63). Cumhuriyet döneminde önemli mevkilerde bulunacak olan Selim Sırrı Tarcan da bu dönemde, Sütlüce'de bir kahvehane toplantısı sonrasında yemin ederek İttihat ve Terakki Cemiyeti'ne katılmıştır.

Kahvehanelerin bir toplanma mekânı işlevi görmesi, toplanılan yerde sohbetin ister istemez siyasete gelmesi kaçınılmaz bir durumdu. II. Abdülhamit, bunun farkına varmış olacak ki dönemin kahvehaneleri hafiyelerin göz hapsinde bulunmaktayd1. Diğer yandan 1908 devrimi sonrası iktidarın gerçek sahibi olacak olan İttihat ve Terakki Cemiyeti kahvehanelerde oluşabilecek bir muhalefeti engellemek istiyordu. Bu nedenle 1910 y1lında askeri mektep öğrencilerinden bazılarının Tavukpazarı ve Şehzadebaşı'nda bulunan kahvehanelere gittikleri haber alınınca derhal tedbir alınması için harekete geçilmiştir. Kahvehane 
sahipleri askeri öğrencileri kabul etmemeleri konusunda uyarılmıştır (Akbulut, 2015, s. 571).

İttihat ve Terakki Cemiyeti kahvehaneleri zaman zaman sanki parti binasıymış gibi kullanmıştır. Örneğin Fevziye Kıraathanesi, Jön-Türk rejimi tarafından ordudan atılan subaylar tarafindan toplantı yapılmak üzere kullanılmış, Orta Asya'daki Türkler hakkında burada bir konferans verilmiş, 1911 yılında Türk Milliyetçilik akımının öncülerinden Yusuf Akçura yine aynı kıraathanede "Türklerin Medeniyete Yaptıkları Hizmetler" üzerine bir konuşma yapmıştır (Ediz, 2008, s. 184). Nihayetinde siyasal rejim kahvehaneleri ideolojisi yaymak, taraftar toplamak vb. bir sürü konuda etkin bir şekilde kullanmıştır.

Meşrutiyet'ten Cumhuriyete giden yolda, üzerine topladığı bütün tepkilere rağmen kahvehaneler toplumun alt, orta ve üst kesimlerinin cami dişında bir arada toplanabildikleri ve böylelikle toplumsal tabaka farkının ortadan kalktığı yegâne mekânlar olma özelliklerini sürdürmüşlerdir (Gregoire ve Georgeon, 1999, s. 76). Tabii bu özellik her zaman siyasi gücün kimi zaman kontrol etmesi gereken bir olgu olmasının yanında, kimi zaman da buradaki toplumsal gücü bir potansiyel olarak algilamasına sebep olmaktadır.

Kahvehanelerin toplumsal ve siyasal işlevleri konusunda bir başka örnek olarak da Kurtuluş Savaşı yıllarını gösterebiliriz. Zira Ankara hükümeti Anadolu'nun birçok yerinde camileri, tekkeleri faal olarak kullandığ 1 gibi kahvehaneleri ve burada toplanan insanları da milli mücadele hizmetinde kullanmıştır. 1918-1922 yılları arasında bazı kahvehaneler Mustafa Kemal'in önderlik ettiği Millî Mücadele hareketinde İstanbul ile Anadolu arasında bir köprü fonksiyonu üstlenmiş, Ankara Hükümeti'nin yasaklanan yayınları bu kahvehanelerde takip edilmiş ve gerekli haberleşme ağı burada sağlanabilmiştir (Öztürk, 2006, s. 89). Aynı zamanda kahvehaneler Millî Mücadele yıllarında önemli bir lojistik görevi de üstlenmiştir. İstanbul'dan gelen para, silah gibi şeyler kahvehane ortamında el altında toplanıp, gizlice Anadolu'ya geçirilmesi sağlanmaktaydı (Belli, 1999, s. 18). Aynı şekilde Ankara'da da kahvehaneler devlet ofisi işlevi olarak da kullanılmıştır. Ankara'da ilk meclis binasının yanındaki Kuyulu Kahve, Millî Mücadele tarihi boyunca, gizli haber alma ve bu haberleri gerekli organlara ulaştırma bağlamında bir istihbarat bürosu görevi görmüştür (Ediz, 2008, s. 186). Öte yandan İstanbul hükümeti ve işgalci devletler de kahvehanelerin bu özelliğini kullanmaya çalışmışlardır. Herhangi bir istihbarat alınabilir beklentisiyle, kahvehanelerde bu dönemde sürekli olarak hafiyeler bulunmaktaydı. Tam tersi bir durumu önlemek için, yani işgalci askerlerden istihbarat ya da bilgi edinilmesini engellemek için işgalci kuvvetlerin komutanları askerlerin kahvehanelere gitmesini yasaklamıştır (Öztürk, 2006, s. 91). Nihayetinde ilginç bir şekilde görmekteyiz ki, kahvehanelerden beslenen ve yarar sağlayan her siyasi oluşum, gücü elde ettikten sonra, kahvehanelere şüpheci gözlerle bakmışlar ve hedef tahtasına koymuşlardır. 
İttihat ve Terakki'nin 1910'daki uygulamaları gibi Ankara hükümeti de Kurtuluş Savaşı'nın ertesinde, kahvehanelerin oluşabilecek potansiyel muhalefetin işine geleceğini anlamıştı. Bu bağlamda 1923-26 yılları arası çıkan çeşitli isyanların da etkisiyle kahvehanelerin kapatılması gündeme gelmiştir. ${ }^{\dagger}$ Ama Cumhuriyet rejimi kahvehanelerin yapılacak devrimlerin uygulanmasında önemli bir yeri olduğunu düşünüyor olmalı ki, kapatma gereği duymamıştır. Zaten harf devriminden hemen sonra kahvehaneler, yeni harflerin öğretilmesi için yapılan örgütlenme faaliyetlerinin içinde yer almış ve bunun yanında inkılâplar için gerekli alt yapının oluşturulmasına yönelik birçok konferans ve bilgilendirme toplantısına ev sahipliği yapmıştır. Ama tabii ki kahvehanelerin ıslah edilmesi planlanmıştı. Çünkü Cumhuriyet Batılılaşmak istiyordu ve kahvehaneler tipik bir Doğu mekânıydı. Bu sebeple kahvehanelerin Batıdaki muadillerine dönüştürülmesi gerekliydi (Ediz, 2008, s. 187). Halkevleri kahvehanelere bir seçenek olarak algılansa da, bir türlü kahvehanenin yerini alamadı. Bu dönemde kahvehaneler üzerinde fazla baskı yoktu; fakat Kemalist devlet zamana ve yerine göre kahvehaneleri kapatmaya kadar gidebiliyordu. Buna en bariz örneklerinden birisi Giresun kahvehaneleridir. Giresun'da findik hasadındaki sorunlar dolayısıyla, halk işsiz bir şekilde kahvehanelerde oturuyordu. Bu durumdan devlet rahatsız olmuş olacak ki, halk boş boş oturup, devleti ve siyasal rejimi eleştirmesin diye kahvehaneleri yerel olarak kapatmıştır (Öncel, 2014). Yani özetle kahvehaneler devletin propaganda yapma mekânı olduğu gibi, gün gelip muhalefet oluşmasını engellemek için kapattığı bir toplumsal mekândı.

Çok partili dönem ile birlikte kahvehanelerin siyasal durumu da değişiyordu. Daha önceleri bir şekilde görece homojen olarak değerlendirilebilecek kahvehaneler giderek bu vasfını kaybetmiştir. Homojenlik kaybı Cumhuriyet'in ilerleyen yıllarında, özellikle köyden kentte göçün hızlandığı 1950'li yıllar sonrasında, memleket kahvehaneleriyle iyice belirginleşecektir. Anadolu kasabalarından gelenler, İstanbul'da kendi kurdukları gecekondu mahallelerinde düzenli olarak belirli bir mekânda bir araya gelecekler ve bu olay aslında kahvehanelerin homojen yapısının giderek kaybetmesindeki son nokta olacaktır (Y1ldı, 2007, s. 166). Zaten memleket kahvehanelerinin devamında, özellikle 1970'li yıllarda sağ-sol çatışmalarının içinde kahvehaneler önemli yer tutmuştur. Siyasi partiler, liderler ve kendini anlatmak isteyen her oluşum soluğu kahvehanelerde almıştır. 70’lerden itibaren yükselen siyasi kutuplaşma, daha önce belirtildiği gibi, kahvehanelerin de ayrışmasına yol açmış; karşımıza büyük katliamlara yol açan kahvehane tarama eylemleri çıkmıştır. Artık bu dönemde sağcı kahvehanesine solcu, solcu kahvehanesine sağcı giremezdi.

† 1926 yılında Takrir-i Sükûn kanununa paralel olarak Denizli Mebusu Yusuf Başkaya’nın kahvehanelerin kapatılmasına ve yasaklanmasına ilişkin verdiği önerge bu mekânların dinsel içerikli mekânlar olmaması ve hükümet tarafından gerçek bir problem olarak görülmemesi nedeniyle reddedilmiştir. 
68 Kuşağı genç üniversite öğrencileri okul yurtlarında baskın yeme ihtimallerine karşı kahvehaneleri aktif olarak kullanmışlardır. Diğer yandan, ülkücüler 1970'lerde kentlerdeki mahalleleri ve mahalle kahvehanelerini kullanarak kendilerine taraftar toplamayı amaçlamışlardır. Zaten bu siyasi ortam, kahvehanelerin 70'lerde ikiye bölünmesindeki ana sebeplerden biriydi. Günümüzde, Irak'ta nasıl Şii/Sünni kahvehaneleri varsa, bundan kırk yıl öncede Türkiye'de mahalle ve kahvehaneler politik ayrışmanın ortasında yer almıştır. Kahvehaneler ve burada oluşan şiddet, siyasal alandaki kırılmaların toplumsal alandaki yansımasıydı

\section{Kahvehanelerdeki Toplumsal Değişim}

Osmanlı Devleti'nde halkın en fazla rağbet ettiği eğlence mekânları kahvehaneler ve meyhanelerdir. Fakat kahvehaneleri meyhanelerden ayıran temel özellik, meyhanelerin işletmecilerinin daha çok Rum veya Ermeni olmasına karşı kahvehanelerin işletmecilerinin Müslüman olmasıdır (Sakaoğlu ve Akbayar, 1999, s. 229). Bu yüzden toplumun bütün kesimlerinin rağbet gösterdiği boş zamanlarını geçirdiği, namaz vaktini beklediği, camiden sonra toplandığı mekânların başında gelmiştir.

Kahvehaneler, yalnızca toplumsal yaşamda bireylerin buluştuğu bir kamusal alan olmanın ötesinde bir öneme sahiptir. Kahvehaneler, bu topraklarda ortaya çıtı̆̆ından beri, hiçbir zaman sadece içecek içilmek uğranan bir yer olmamış, bireylerin toplumsallaştığ 1 , toplumsal siyasallaştığ bir mekân olmuştur. İşte bu haliyle Osmanlı Devleti'nden Cumhuriyet Türkiye'sine kalan miraslardan birisi de kahvehaneler ve kahvehane kültürü olmuştur. Kısaca kahvehaneler ya da kıraathaneler sosyal kaynaşma mekânlarının başında gelmekteydi. Buralarda günlük bütün gazeteleri, mecmuaları, hatta bazı kitapları bulmak mümkündü (Toros, 1988, s. 74). Doğal olarak bu gazeteler, dergiler kahvehanelerde ortaklaşa okunur ve ortak bir kanaat ortaya çıkardı.

İşlevsel olarak bakıldığında kahvehanelerin bazı ayrışmalara sebep olduğunu söyleyebiliriz. Zira özellikle son Osmanlı döneminde okuma yazma oranın İstanbul'da artmış olmasıyla bazı kahvehanelerin yapısının değiştiği açık olarak görülmektedir. $\mathrm{Bu}$ tür kahvehanelere Taha Toros'un deyimiyle zaten kalem sahipleri gelmeyi tercih ederlerdi. Cumhuriyet döneminin bu dönemden ayrilan en önemli yönü de kuşkusuz buydu. Çünkü ilk Cumhuriyet erken yılları Osmanlı dönemi gibi homojen bir yapı arz etmediği; artık bu yapının kahvehanelerde yavaş yavaş çözülmeye başladığı yıllardır. Örneğin; vilayet binasının karşısındaki 'İhsan Klraathanesi' aslında dönemin orta seviye bürokratlarının tercih ettiği bir yerdi. Öğle aralarında vilayet binası ve çevre devlet kurumlarında çalışan devlet memurları bu kahvehanede buluşup, zamanın güncel konuları hakkında konuşuyorlardı (Toros, 1988, s. 75). Öte yandan alt kesimin oturduğu Sütlüce'deki 'Anadolu Kıraathanesi' hem gelen müşterilerin ait olduğu sınıflar temelinde hem de fiziksel olarak 'İhsan Kiraathanesi'nden farklılık 
göstermekteydi. Alt sınıfların gittiği kahvehaneler ya da geleneksel tarz işleyen kıraathanelerin kısa tabureler kullanmaya devam ettiği görülürken, orta üst sınıfların sıklıkla uğradığı kıraathanelerin Cumhuriyet döneminde artık giderek normal Batılı tarz sandalye, masa kullanılmaya başlandığı görülmektedir.

Diğer bir taraftan değişimin bir başka göstergesi de, Cumhuriyet'in ilk yıllarında edebiyatçılara, akademisyenlere rastlayabileceğimiz kahvehaneler olmakla birlikte, işçileri kahvesi ve gazino olarak anılan çalgılı kahvehanelerde mevcuttur. $\mathrm{Bu}$ bağlamda aslında kahvehanelerin giderek sınıfsal anlamda farklılaştığını söyleyebiliriz. Buna bariz örneklerinden birisi 1950'lilere kadar varlığını sürdüren "Beyazıt Küllük Kahvehanesi" ve müşterileridir. Bu kahvehane o dönemin İstanbul Üniversitesi hocalarının ve öğrencilerinin kaynaştığı bir mekândı. Öyle ki sadece hocalar ve öğrencileri değil; aynı zamanda Türk edebiyatının ve bilim hayatının önde gelen isimleri: İbnülemin Mahmud Kemal İnal, Mükrimin Halil Yınanç, Rıfkı Melûl Meriç, Ali Canip Yöntem, Hilmi Ziya Ülken, Peyami Safa, Kilisli Rlfat Bilge, Kenan Hulusi Koray, Reşad Nuri Güntekin, Fuat Köprülü, İsmail Hakkı Uzunçarşılı, Sadri Ethem Ertem, Nurullah Ataç, Neyzen Tevfik, İbrahim Alaeddin Gövsa, Agâh Sirrı Levend, Abdülhak Hâmid, Yahya Kemal, Midhat Cemal Kuntay, Faruk Nafiz Çamlıbel, Necip Fazll Kisakürek, Yusuf Ziya Ortaç, Orhan Seyfi Orhon, Ahmet Muhip Dıranas, Hâlit Fahri Ozansoy, Reşat Ekrem Koçu, Sabri Esat Siyavuşgil gibi isimlerin sıklıkla görüldügü mekândır (Ayvazoğlu, 2010, s. 134-135; Y1ldız, 2015, s. 96-107). Hatta bu kahvehane öyle bir yerdi ki 1933 'te yapılan üniversite reformundan sonra yurt dışından getirilen yabancı hocalar bile burada yani "Küllük”te toplanıyorlardı (Ayvazoğlu, 2010, s. 133). Küllük Kahvehanesinin müdavimlerinden Edebiyat Fakültesi başkâtibi şair Sıtkı Akozan'ın "Küllüknâme" adlı bir şiiri bile bulunmaktadır.

Küllük Kahvehanesinin müdavimlerinin ve bu müdavimlerin bazı özelliklerinin belirlenmesinde "Küllüknâme" şiiri büyük önem arz etmektedir. Yusuf Çağlar, Türk Edebiyatı Dergisindeki yazısında Kesriyeli Sitkı Akozan'ın bu şiirine yer vermiştir (Çağlar, 2011, s. 48-52). Görüldüğü gibi İstanbul özelinde birkaç kahvehanenin kültür, eğitim vb. konularda giderek diğerlerinden farklılaştığı rahatça anlaşılmaktadır.

\section{Kahvehaneden Kafeye Tarihsel Süreç}

Yukarıdaki bölümde bahsettiğimiz durum, yani bazı kahvehanelerin giderek elitleşmesi, 1980 sonrası Türkiye'de neo-liberal politikalarla birlikte yaşanan değişim karşımızı yeni bir olguyu 'Kafe'leri çıkarmıştır. 1980 darbesi ve onun eklentisi olarak sunulan yeni hayat biçimi, insanları Batıdaki gibi kızlı, erkekli oturulan kafelere yöneltmiştir. Önceleri siyasal, etnik, politik olarak ayrılan kahvehaneler, darbeyle birlikte bu özelliklerinin hepsinden kurtulup yeni bir kimlik kazanmıştır. Bu kimlik ilerleyen yılların getireceği tüketim alışkanlığıyla da ilgiliydi. Tüketim 'bireyin kendisine ayrllan 'özel' alanda özgürlük ve kişisel oyun alanı marjını yeniden elde edeceği marjinal bir belirlenimsizlik sektörü 
değildir. Tüketim etkin ve kolektif bir davranıştır, bir zorlama, bir ahlak ve bir kurumdur. Tüketim tam olarak bir toplumsal değerler sistemi, bu terimin grup bütünleşmesi ve toplumsal denetim işlevi içerlediği bir toplumsal değerler sistemidir" (Baudrillard, 2004, s. 95). Bu nedenle yeni tüketim alışkanlığında kahvehaneler geri planda kalmış; ama yeni tip kahvehaneler yani kafeler günümüz dünyasında egemen olmuşlardır. Bu bağlamda ünlü kahve zinciri 'Starbucks' insanlara belirli bir bireysel özgürlük alanları sunmuştur (Akarçay, 2012, s. 194). Eski kahvehanelerdeki enformellik daha doğrusu insanların birbirlerine unvansız hitapları, bu yeni kafelerde bulunmamaktadır. Garson ya da kasiyer müssterilere efendi/hanım gibi ek unvanlarla seslenmek zorun kalmışlardır (Akarçay, 2012, s. 195). 2003 yılında Türkiye pazarına giren Starbucks, tam on yılda 164 şubeye ulaşmıştır. Bu muazzam bir büyümedir; fakat bu büyümeyi "kahvehaneler işlevselliğini kaybetmiş yerini kafeler almış, gerçeğinin bariz bir göstergesi olmuştur" şeklinde yorumlayabiliriz. Starbucks 'tan sonra dünyanın önde gelen kahvecileri de Türkiye pazarına girmiştir. Bu kafeler kentli orta sınıf ve üst orta sınıfın, kentli genç profesyonellerin kahve molaları, iş görüşmeleri, dost buluşmaları ve belki de en önemlisi, geleneksel olarak kahve tüketiminin oturarak, sohbet ederek, belli bir mekânda tüketilmesinin dışında, al-götür şeklinde alınarak içilen kahvenin yürüyerek işe yetişirken, okula giderken, toplu taşıma aracına binerken başlanması daha önce geleneksel kahvehanelerin sunamadığı yeni gelişmelerdi (Akarçay, 2012, s. 196). Ayrıca bu tarzdaki kafeler insanlara uzun süre oturma, ücretsiz internet gibi imkânlar sunarak, bir şekilde insanların günün uzun saatlerini buralarda geçirmelerini sağlamaktadırlar. Erhan Akarçay'ın makalesinde bu konunun çok ilginç bir tartışması gösteriliyordu Eskişehir özelinde. Zira makaleye göre, Eskişehir'de Starbucks ve türevleri gibi kafelerin açılmasının nedeni olarak öğrenciler gösteriliyordu. Eskişehir büyük bir öğrenci nüfusuna sahipti ve bu nüfus genel olarak İstanbul, Ankara ve İzmir'den öğrencilerden oluşuyordu. Geldikleri şehirlerdeki gibi modern tip kızı/erkekli kafelerin bulundukları şehirde de açılması için aktif kampanyalar yürütüyorlardı (Akarçay, 2012, s. 198). Zaten açıldığı ilk gün binlerce kişinin uğraması bize bu tip yerlerin mekânsal olarak tercihini net olarak göstermektedir.

\section{Sonuç}

16. yüzyılın ortasından itibaren gündelik Osmanlı toplumunun gündelik yaşamına giren kahvehaneler, yerel/mahalle ölçeğinde sivil mekân (ev) ile dini mekân (cami) arasında yaşanılan içe dönük geleneksel yaşam tarzını dışa dönük bir kültürel yapılaşma aşamasına getiren önemli mekânlar olmuştur. Başka bir ifadeyle, mahalle sakinlerinin sivil ve dini mekânlardan bağımsız olarak sokak kültürünü tanımalarına, kent yaşamına doğrudan katılmalarına ve toplumsallaşmalarına imkân veren mekânlar olmuştur. Bütün toplumsal kesimlerin ve meslek mensuplarının buluşma mekânı olan kahvehaneler yalnızca kahve, tütün, çubuk, nargile gibi keyif maddelerinin içildiği ve bu mekâna özgü oyunların oynandığı bir yer değil, onun da ötesinde Osmanlı toplumunda ilk sivil 
örgütlenmenin filizlendiği, siyasal toplumsallaştı̆̆ı, sosyo-kültürel yaşamın teneffüs edildiği birer kültürel merkezler de olmuşlardır.

Kahvehaneler, küreselleşme olgusunun artmasıyla birlikte, özellikle de 1980 sonrası yaşanan toplumsal değişime bağlı olarak farklılaşmıştır. Kahvehanelerin işlevleri, mekânsal kurguları, sosyallik örüntüleri, iletişim izleği ve davranış kalıpları itibariyle farklı görünümlere büründügünü gözlemlemekteyiz. Kahvehaneler çok amaçlı cafelere, oyun salonlarına, sosyal kulüplere dönüşerek işlevlerini farklı görüntülerde ve isimlerde devam ettirmeye çalışmaktadırlar. Özellikle de büyük şehirlerdeki kahvehanelerin giderek, yeni/modern görünümler aldıkları dikkat çekmektedir. Çoğu, "Kafe/Cafe" nevinden adlar ile anılsalar da buralar esasta kahvehane kavramını geniş anlamda karşılayacak bir içeriğe sahiptirler. Oluşturdukları sosyallik bağlamı hiç kuşkusuz; "bireysel temsil", "grupsal aidiyet", "cemaatsel kimlik", "toplumsallık bağlamı" vs. gibi değişik boyutlara sahiptir. Bu toplumsallık bağlamı, bazen geçici birliktelikler şeklinde kendisini göstermekte; bazen de toplumsallığın derin uzantılarını mekânın kurgusu içinde yeniden üretilmektedir. Bu mekânlar; bir tür yaşam pratiği olarak gündelik hayatın vazgeçilmez durakları, buluşma noktaları olmaya devam etmektedir. Bu yönüyle sosyolojik bir derinlik taşımaya devam etmektedirler.

\section{Kaynakça}

Akarçay, E. (2012), Kâh kahvehane kâh café: küreselleşen Eskişehir'de kahve tüketimi üzerine kuramsal bir giriş. Galatasaray Üniversitesi İletişim Dergisi, (2), 181-202.

Akbulut, U. (2015), Tanzimat ve Meşrutiyet dönemlerinde kahvehanelerden kaynaklanan sosyal sorunlara dair bazı tespitler. Atatürk Üniversitesi Türkiyat Araştırmaları Dergisi, (54), 561-583.

Ayvazoğlu, B. (2010), Dersaadet'in kalbi Beyazıt, İstanbul: Heyamola Yayınları.

Baudrillard, J. (2004), Tüketim toplumu, İstanbul: Ayrıntı Yayınları.

Belli, M. (1999), Mihri Belli'nin anıları -insanlar tanıdım-1. İstanbul: Doğan Yayıncilik.

Çağlar, Y. (2011), Bir zamanlar bir küllük vardı. Türk Edebiyatı Dergisi, 456, 4852.

Ediz, İ. (2008), 'Osmanlı'dan Cumhuriyet'in ilk yıllarına kahvehaneler ve sosyal değişim, Sakarya Üniversitesi Fen-Edebiyat Dergisi, 8(1), 179-189.

Gökbayır, S. (2012), Gizli bir cemiyetten iktidara: Osmanlı İttihat ve Terakki Cemiyeti'nin 1908 seçimleri siyasi programı, Çankırı Karatekin Üniversitesi SBE Dergisi, 3(1), 61-96.

Gregoire, H. D. ve Georgeon, F. (1999), Doğu'da kahve ve kahvehaneler, İstanbul: Yapı Kredi Yayınları. 
Hattox, S. R. (1998), Kahve ve kahvehaneler: bir toplumsal içeceğin Yakındoğu'daki kökenleri, İstanbul: Tarih Vakfı Yurt Yayınları.

Öncel, N. C. (2014), Twitter yokken kahvehaneler kapatılırdı, Hürriyet Gazetesi, 14 Mart 2014.

Öztürk, S. (2006), Cumhuriyet döneminde kahvehane ve iktidar, İstanbul: Kırmızı Yayınları.

Sakaoğlu, N. ve Akbayar, N. (1999), Binbir gün binbir gece: Osmanlı'dan günümüze İstanbul'da eğlence yaşamı, İstanbul: Denizbank Yayınları.

Toros, T. (1998), Kahvenin öyküsü, İstanbul: İletişim Yayınları.

Yıldız, M. A. (2015), Beyazıt'ta bir kültür ortamı: Küllük kahvesi, Mavi Atlas, 4, 96-107.

Yıldız, M. C. (2007), Kahvehane kültürü, İstanbul: Beyan Yayınları. 


\title{
Spatial Functionality of Coffeehouses in the Republican Period and Coffeehouses as Political Figure
}

\begin{abstract}
Extended Abstract

\section{Introduction}

In the last period of the Ottoman Empire and in the early period of the Republic, both the structures and functional features of coffeehouses that have existed for centuries have changed sharply. Undoubtedly, the changing world, politics and economy were influential in this case. With the last quarter of the 19th century, the state was changing, and even so, it was rapidly modernizing. In this process, together with the state, societies and institutions began to undergo political, economic and structural changes. Of course, this process of change and transformation has caused many socio-political events. In this process, spaces such as coffeehouses, which are frequented by the society, had been forced between the two options: they would either adapt to the change or they would disappear. Indeed, by acting like a living organism, coffeehouses have gone through certain evolutions and survived to the present day.
\end{abstract}

\section{Method}

The study focuses on the evolutionary process and the socio-political functions of coffeehouses from the time of the Ottoman Empire to the present day. In the Republican era, while dealing with the adventure of coffee houses, the Second Constitutional Monarchy began. First of all, it has been examined how coffeehouses were a political space from the Second Constitutional Monarchy to the present, and then how coffeehouses were and they moved away from common social cohesion as before, and how they changed in the public space in the modern sense. Following the reform of the public space in the republican period, the change of the coffee culture was analyzed. Finally, the process of transforming coffeehouses into modern, secular cafes has been discussed.

\section{Results and Discussion}

Historically, coffeehouses are an important element of 19th century politics. With the first official newspaper Takvim-i Vakayi (1831), coffee houses were introduced to the newspaper; the importance of coffeehouses in social and political sense has increased. Newspaper, mass media in the first place that takes place in coffeehouses. Until today, it has become an integral part of coffeehouses. It is inevitable for coffeehouses to function as a gathering space, and the conversation in the gathered place is inevitable. Abdulhamid II would have realized that the coffeehouses of the period were under the watchful guard of agents. On the other hand, Committee of Union and Progress, which would be the real owner of the power after the revolution of 1908, wanted to prevent an opposition that could occur in the coffeehouses. The Committee of Union and Progress used coffeehouses from time to time as if it were a party building. On the way from the Constitutional Monarchy to the Republic, despite all the reactions, coffeehouses remained the only space where the lower, middle and upper parts of the society could gather together outside the mosque and thus the social layer difference disappeared. The Ankara government also understood that after the Independence War, coffeehouses could be used by the potential opposition. In this context, the closing of coffeehouses was discussed with the effect of various riots between 1923 26 years. Although "Halkevleri" were perceived as an option to coffeehouse, they could not replace the coffeehouse. There was not much pressure on coffeehouses in this period. But the Kemalist state could go as far as closing the coffeehouses by time and place. With the multiparty period, the political situation of coffeehouses was changing. Previously, coffeehouses, which could be considered as relatively homogeneous, have gradually lost this character. After the 1950s, 
when the migration from the village was accelerated, it will become more evident by the hometown's coffeehouses(memleket kahvehaneleri). Those coming from the Anatolian towns will come together in a certain place in their own shantytown neighborhoods in Istanbul and this event is actually the last point in the loss of homogenous structure of coffee houses. After 1980 in Turkey, with the neoliberal political changes, "café" emerge as a new social phenomenon. The 1980 coup and the new style of life that emerged in the process that followed led the people to western style cafes. Previously, the coffeehouses, which were politically, ethnically, politically separated, had gained a new identity with all these features. In the new consumer habit, coffeehouses have been left behind; but the new type of coffeehouses, cafes have dominated today's world. These cafes have become space for coffee breaks, business meetings and friendly gatherings of the urban middle class and upper middle class, urban young professionals. The habit of coffee consumption is changed. The coffeehouses had to adapt to the spatial change in line with the preferences of the new middle class, or left their places to cafes.

\section{Conclusion}

The coffeehouses differed with the increasing globalization phenomenon, especially due to the social change experienced after 1980. We observe that coffeehouses have different aspects in terms of their functions, spatial constructs, patterns of sociability, communication track and behavior patterns. Coffeehouses transformed into multi-purpose cafes, game halls, social clubs. Especially, it is noteworthy that coffeehouses in big cities are increasingly becoming new/modern vision. These places continue to be the indispensable stops and meeting points of everyday as a kind of life practice. In this respect, they continue to carry a sociological depth. 